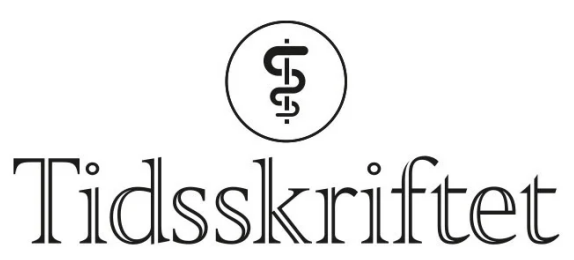

DEN NORSKE LEGEFORENING

\title{
Nyttig bok for hjelpere
}

\author{
ANMELDELSER
}

\section{REIDAR TYSSEN}

Professor, spesialist i psykiatri, Avdeling for atferdsmedisin Institutt for medisinske basalfag Universitetet i Oslo

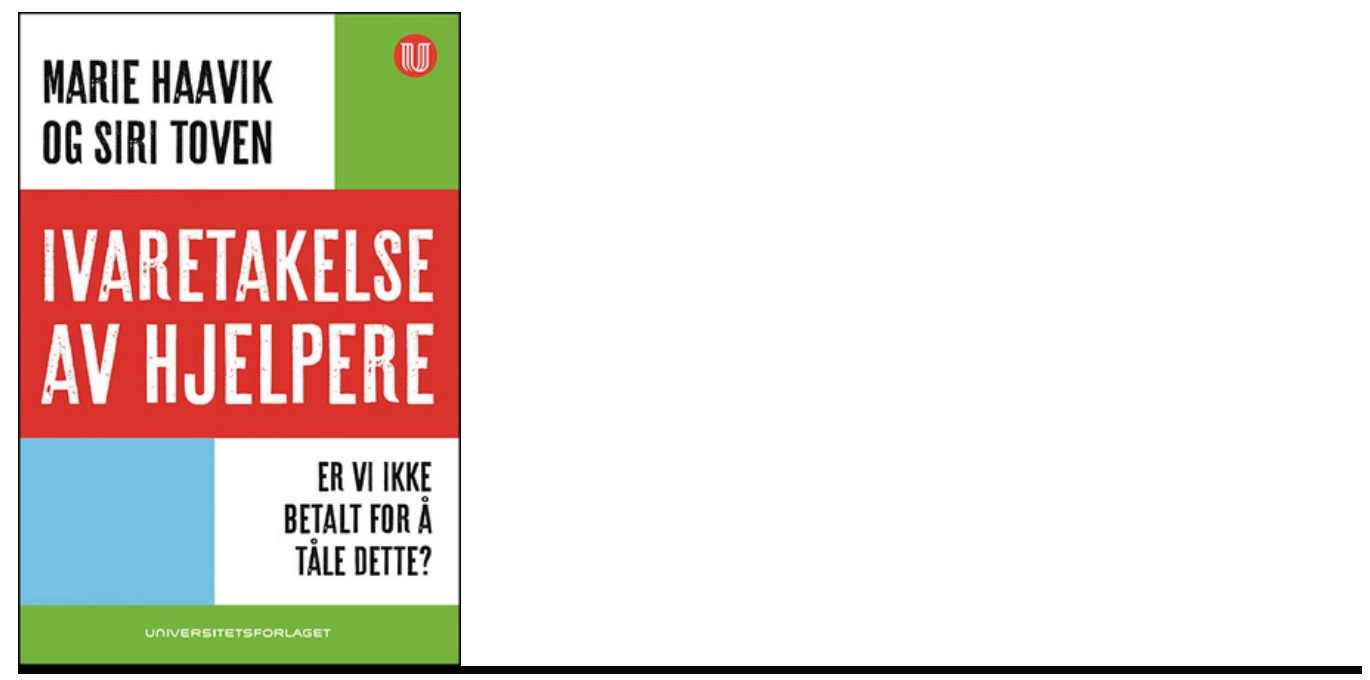

Marie Haavik, Siri Toven

Ivaretakelse av hjelpere

Er vi ikke betalt for å tåle dette? 16o s. Oslo: Universitetsforlaget, 2020. Pris NOK 399

ISBN 978-82-15-03449-2

I all diskusjon om stress og utbrenthet i helseprofesjonene er dette en forfriskende og nyttig bok! Forfatterne er psykologspesialister med lang erfaring fra krevende pasientmøter, som arbeid med traumatisk vold og barnevernssaker. De har også drevet veiledning og kurs for hjelpere. Hjelpere er her mennesker i helse- og omsorgsyrker, inkludert leger. Forfatterne ønsker å beskrive ivaretakelse fra både et individuelt og et organisatorisk perspektiv. De lykkes nok best med det første.

Boken har ti oversiktlige og tiltalende korte kapitler. Innledningsvis beskrives det risikofylte ved krevende pasientarbeid - som utbrenthet, empatiutmattelse (compassion fatigue) og sekundær traumatisering. Deretter vektlegges betydningen av ledelse og 
kollegafellesskap. Det følger tre kapitler om selvivaretakelse, ett kapittel om det å være ny hjelper, og et viktig avslutningskapittel om det gode i hjelpearbeidet.

Det beste med boken er at det er så mange eksempler på selvivaretakelse- også fra forfatternes eget yrkesliv. Eksemplene vil være praktiske og tankevekkende for mange i omsorgsyrkene, tror jeg. Forfatterne skriver svært muntlig og lettlest - og legger nok mest vekt på praktisk erfaring, mindre på teori. Boken blir kanskje vel muntlig i formen noen steder, og kunne kanskje vært kortet enda mer. En svakhet med boken er en svært tungvint måte å referere litteratur på, der en først må inn i sluttnoter og deretter inn i en litteraturliste. Det henvises også ofte til sekundærlitteratur, som hefter fra Statens arbeidsmiljøinstitutt (f.eks. med hensyn til sentrale sosialpsykologiske modeller om krav, kontroll og autonomi).

Likevel skjemmer ikke dette helhetsinntrykket av en praktisk og nyttig bok for helsearbeidere - også leger. Dette gjelder kanskje spesielt unge leger og de med ledelsesansvar. Spesielt likte jeg fokuset på de krevende første årene i karrieren og det vanskelige i lederrollen. Et annet dilemma som er vettug beskrevet, er den vanskelige balansen mellom å holde taushetsplikten og nødvendig utlufting for sine nærmeste.

Boken inneholder flere praktiske tips for å få til en god balanse mellom jobb og privatliv. Kapitlet om hvordan gode opplevelser på arbeidsplassen kan fremheves for andre kolleger, var spesielt inspirerende. Boken kan være til god hjelp for å motvirke utbrenthet i disse krevende yrkene.

Publisert: 22. februar 2021. Tidsskr Nor Legeforen. DOI: 10.4045/tidsskr.20.0877

(C) Tidsskrift for Den norske legeforening 2023. Lastet ned fra tidsskriftet.no 26. april 2023. 